Marquette University

e-Publications@Marquette

Finance Faculty Research and Publications

Finance, Department of

9-1-2005

\title{
Who Bears the Balloon Risk in Commercial MBS?
}

Mark Eppli

Marquette University, mark.eppli@marquette.edu

Charles C. Tu

University of San Diego

Accepted version. Journal of Portfolio Management, Vol. 31, No. 5 (September 2005): 114-123. DOI. (C) 2005 Institutional Investor, Inc. Used with permission. 


\title{
Who Bears the Balloon Risk in Commercial MBS? In some cases it can be investment-grade tranches.
}

\author{
Mark J. Eppli \\ Bell Real Estate Chair, Department of Finance \\ Marquette University \\ Milwaukee, WI \\ Charles C. Tu \\ Burnham-Moores Center for Real Estate, University of San Diego \\ San Diego. CA
}

Global capitalization of commercial mortgage-backed securities (CMBS) today exceeds $\$ 500$ billion, and CMBS have been included in several fixed-income indexes in the past several years. As the CMBS market continues to grow, understanding the risk characteristics of these investments becomes more important to a broader market of investors.

To date, much of the research on commercial mortgages and CMBS has focused on the impact of default during the term of the loan (i.e., term default), and has paid little attention to balloon or extension risk. Lehman, Freydberg, and Tcherkassova note about balloon risk for 2004 vintage CMBS investments: 
While we admit we are at a loss for forecasting future extensions we think that investors, particularly those managing buy and hold portfolios, should at least consider the potential implications of loan extensions when determining relative value [2004, p. 2] (emphasis in original).

The newness of the CMBS market and the changing attributes of CMBS mortgage pools make it difficult for researchers to address the issue of balloon risk empirically. First, to date few CMBS investments have gone through a complete ten-year hold-to-maturity investment cycle, and none has experienced an investment cycle in an increasing interest rate environment, thus greatly limiting the data available to test the impact of balloon risk on CMBS investments.

Second, CMBS pools that have matured have different characteristics from more recent pools. For example, the average CMBS pool size for the 1987-1995 CMBS issuances was $\$ 144.0$ million, different from the $\$ 1.1$ billion average pool size in 2004 ; the average loan size in CMBS pools has grown from $\$ 5.4$ million in 1997 to $\$ 11.0$ million in 2004; and the property type makeup of the pools has changed from heavily weighted toward multifamily mortgages to domination by office and retail mortgages.

Additionally, several current market factors may contribute to balloon risk in current CMBS investment tranches. Low commercial mortgage interest rates (generally below 6.0\%) and increases in property values over the past decade (with little if any appreciation in property income) imply a reasonable chance that interest rates will rise or property values will fall when commercial mortgages issued today mature in the coming decade, thus increasing the probability of balloon risk. That said, balloon risk today on loans issued in the mid-to late 1990 s is likely to remain low as current low interest rates allow for generous debt service coverage and lower loan-to-value ratios on appreciated property values, permitting relatively easy refinancing.

Another potential contributor to balloon risk for current-vintage CMBS pools is relatively low subordination levels. Pool subordination levels have fallen dramatically in recent years, with subordination rates for conduit fusion transactions cut in half across all tranche levels since 1998 (see Exhibit 1).

Furthermore, the increasing number of interest only and partially interest-only loans in new CMBS issues may also cause higher 
balloon risk. Before 2000, interest-only or partial interest-only CMBS loans were virtually non-existent, but in the fourth quarter of 2004, $50 \%$ of conduit CMBS loans were partial interest-only or full interestonly loans (see Exhibit 2).

While balloon risk in commercial mortgages may be a significant contributor to the overall risk of investing in commercial mortgagebacked securities, to date little research has focused on its impact on CMBS pricing. There are two primary reasons for the limited balloon risk research. First, as discussed earlier, there are limited data on balloon risk. Second, it is difficult to model term default risk and balloon risk simultaneously and then measure the impact of these risks on CMBS investment tranches under changing market conditions.

Our primary purpose is to investigate the impact of balloon risk on the pricing of multiclass commercial mortgage-backed securities investments.

\section{CMBS Pricing Model}

To determine the credit risk in CMBS investments, we apply a commercial mortgage whole-loan pricing model to a CMBS framework. Specifically, we complete a series of simulation analyses that measure the balloon risk premiums of various CMBS tranches under changing pool characteristics and market conditions, such as lower tranche subordination levels, higher mortgage interest rates, and interest-only loans.

Our CMBS valuation model has two separate stages. In the first stage, a whole loan's cash flow stream is projected on the basis of borrower default behavior. Then after the cash flow streams for the individual whole mortgages are simulated, mortgage cash flows are combined across all loans in the pool and allocated among the various CMBS investment classes in the second stage.

To estimate the whole-loan cash flows, we use our model in Tu and Eppli [2003], which has two key distinguishing features. First, it considers two triggers when simulating borrowers' default decision: a property cash flow trigger, and an asset value trigger. Second, it takes into account the possibility of mortgage extension or balloon risk. ${ }^{1}$ These unique features of the model allow us to incorporate balloon risk into a CMBS framework and then assess its impact on various investment tranches. Appendix A describes the double-trigger default model in more detail. 
In the second stage, individual mortgage cash flow streams are combined across all loans in the pool and allocated among the CMBS investment classes. The value of each CMBS tranche is then calculated as the present value of the cash flow stream on a risk-neutral basis.

To complete the two-stage analysis, we use Monte Carlo simulation to derive the values and credit risk premiums for each CMBS tranche. ${ }^{2}$ Each simulation path has three state variables (interest rate, property value, and property cash flow) that are updated each month (see Appendix B). Using the monthly updated variables, the borrower makes a default decision based on the contemporaneous loan-to-value ratio (LTV) and debt service coverage ratio (DSC). ${ }^{3}$

If default occurs, the loan is foreclosed and the property is sold. The sale price, net of transaction costs, is then included in the CMBS pooled cash flows. If default does not occur, the scheduled mortgage payment is made, and the default decision is considered for the next period under a set of updated state variables.

If a borrower does not default during the loan term, we then examine whether the property can be refinanced at mortgage maturity. Using the contemporaneous property value, mortgage interest rate, property cash flow, and underwriting standards, we estimate the loan amount the borrower is able to refinance (i.e., the justified refinance loan amount). If the justified refinance loan amount is equal to or greater than the outstanding mortgage balance, the mortgage balloon amount is paid off; otherwise, one of three paths is followed: 1) the borrower will use other equity capital to pay off the loan; 2) the borrower will default; or 3) the borrower and the lender will negotiate an extension.

If the loan is extended, we assume the borrower will continue to make periodic debt service payments and follow the same payment/default conditions during the term of the loan. At the end of each extended month, the mortgage may be paid off (if the justified refinance loan amount exceeds the loan balance); in default (if both default triggers are satisfied); or extended again (otherwise) based on the new market and property conditions. Additionally, it is assumed that the mortgage can be extended for up to two years, at which point the borrower will be forced to liquidate the property and terminate the mortgage if neither default nor payoff has occurred during the twoyear extension period. ${ }^{4}$ 
After the cash flow streams for the $50 \% \mathrm{~N}$ mortgages in the CMBS pool are simulated, the cash flows are combined and allocated among CMBS investment classes. While interest payments and principal repayments (including scheduled amortization and principal recovery when default occurs) are distributed top-down to CMBS tranches, lost interest and the reduction in face amount of the principal (due to the shortfall between loan balance and principal recovery) are allocated bottom-up.

The cash flow for each CMBS tranche is calculated monthly, and the cash flow stream is discounted on a risk neutral basis to determine each tranche value. The credit risk premium of a CMBS tranche over the risk-free rate is then calculated based on the tranche value.

\section{Simulation Parameters}

We must now populate the CMBS pricing model with a set of parameters that reflect the behavior of the market participants. We consult a variety of academic journals, professional publications, and industry experts to select a set of reasonable and logical parameters.

We begin the model parameterization by considering a CMBS pool consisting of 10-year commercial mortgages with a 30-year amortization schedule. To isolate the impact of credit risk on mortgage pricing, we assume that the mortgages are non-callable. ${ }^{5}$ The two primary mortgage underwriting standards at loan origination and at loan refinancing are a $67 \%$ LTV and a 1.4 DSC.

Most commercial mortgage underwriters require some level of cash reserves or escrows to dampen cash flow volatility created by capital improvements, tenant improvements, and other expected and unexpected cash flow variances. ${ }^{6}$ When a property's contemporaneous debt service coverage ratio slips below 1.0, the borrower can then avoid immediate default by funding the property cash flow shortfall with funds from a reserve account. We have no empirical data on how long a borrower is able to delay default through the use of a reserve account, so we present three models in the simulation analysis to illustrate the effects of including the cash flow default trigger on CMBS pricing.

Model 1 is a single-trigger, asset value-only, default model. The other two models assume that the borrower has sufficient reserves to fund a one-month (Model 2) and three-month (Model 3) cumulative debt service shortfall in the previous 12-month period, where a one- 
month shortfall is equal to one month's debt service payment. Models 2 and 3 are double-trigger default models that include a contemporaneous LTV trigger and a contemporaneous cash flow trigger that both must be met for the property to be in default.

Once a property is in default, it is assumed that the average time to foreclosure is 12 months and that the property value recovery rate is $90 \%$ with a standard deviation of $5 \%$, consistent with the commercial mortgage default update in Esaki and Goldman [2004]. Additionally, there is a carrying cost per month of0.5\% of the loan balance. These foreclosure assumptions hold for both term default and extension default. For each parameterization, 10,000 Monte Carlo paths are generated to ensure sufficient convergence to the true tranche value.

\section{CMBS Pricing Results-Base Case}

In the base case analysis, CMBS subordination levels are averages for the 1998-2004 period. ${ }^{7}$ To isolate the impact of balloon risk on overall credit risk, we begin by presenting credit risk premiums without including the effects of loan extension in Exhibit 3. At the whole-loan level, the term default risk premiums are 81 basis points for the single-default trigger model (i.e., Model 1). Including a cash flow trigger in Models 2 and 3 reduces the risk premiums to 79 and 64 basis points, respectively.

An interesting finding in Exhibit 3 is that the addition of a property income default trigger reduces whole loan default risk premiums while increasing the default risk premium for the investment-grade tranches. Initially these results seem counterintuitive, i.e., that a whole loan with lower risk premiums has higher risk premiums for the investment-grade tranches. Yet after a closer look, these findings are reasonable and can be explained as follows.

Under the Model 3 assumptions, weaker or underperforming loans are kept current using a cash flow reserve account, and without that reserve would otherwise have defaulted. By stringing along these weaker loans, the eventual default, when it does occur, has a significantly higher loss rate. ${ }^{8}$

While the probability or frequency of default at the whole-loan level is reduced in Model 3 (as the financial condition of some of the properties will improve), the increase in loss severity for the loans that default increases the risk of the investment-grade tranches. The non- 
investment-grade tranches, on the other hand, maintain tranche cash flows longer in Model 3, thus reducing the risk of investing in lowerrated tranches.

Overall, adding a second property cash flow trigger reduces loss frequency but increases loss severity at the whole-loan level. This shift from lower loss frequency to greater loss severity at the whole-loan level shifts the default risk in CMBS securities from the lower-rated tranches to the higher-rated tranches. ${ }^{9}$

In Exhibit 4 we isolate the impact of balloon risk on the pricing of CMBS investments. Panel A presents total credit risk premiums (combined term default and balloon risk premiums) for CMBS tranches across the three default models, and Panel B presents the balloon risk premiums. The results reveal that the increase in whole-loan risk premiums is only 3 to 7 basis points when balloon risk is considered. Of the three models presented in Panel B, Model 3 has the highest balloon risk premiums. The higher balloon risk premiums for Model 3 are expected, as weaker loans are able to make it to maturity without defaulting but at maturity are forced to extend as they are too weak to be refinanced.

When we assess balloon risk premiums at the tranche level, the Model 3 balloon risk premiums are highest across all investment tranches except for the AAA tranche, which does not incur any credit risk premium across the three models. These results are important, as what is thought to be safer underwriting procedures (i.e., increasing property escrows) reduces default frequency, but increases loss severity and balloon risk premiums across all investment tranches. Furthermore, with a relatively small 7 basis-point increase in the whole-loan credit risk premium that is attributable to balloon risk, total risk premiums for the $A, B B B, B B$, and $B$ tranches increase by 13 to 84 basis points.

Overall, we find that adding a second property income default trigger and including balloon risk marginally affects the pricing of whole loans but significantly affects the pricing of investment-grade CMBS tranches.

\section{CMBS Pricing Results-Comparative Analyses}

To better understand the impact of balloon risk on CMBS pricing, we also change the simulation parameters to reflect alternative states of the property and capital markets. Specifically, we 
assess the effects on total credit risk and balloon risk of: 1) lower subordination levels; 2) rising mortgage interest rates; and 3) replacing amortizing loans with interest-only loans.

In these comparative analyses we focus on Model 3 simulation results, assuming that rational borrowers would default only when the property equity position and property cash flow are both negative and when a debt service reserve account is depleted appears reasonable. ${ }^{10}$

The base case credit risk analysis presented in Exhibit 4 presumes average subordination levels for the period 1998-2004. Over this period of time, however, the subordination levels of CMES tranches have fallen substantially. The 2004 subordination levels are approximately one-half the 1998 levels and as of this writing are at alltime lows (see Exhibit 1 for subordination levels in 1998, 2001, and 2004).

In Exhibit 5 we examine the impact of balloon risk on the pricing of CMBS tranches using 2004 subordination levels. Whole-loan credit risk premiums in Exhibits 4 and 5 are identical, as the CMES structure does not affect the characteristics of individual loans. That said, tranche credit risk premiums change dramatically. Total credit risk premiums extend well into the AA tranche, increasing from 16 to 81 basis points.

While the balloon risk premiums relative to the total credit risk premiums maintain approximately the same relationship (20\%-25\% of the total risk is balloon risk in the investment-grade tranches, and $10 \%-15 \%$ of the total risk is balloon risk for non-investment-grade tranches), balloon risk premiums become two to five times higher for the $A A, A$, and $B B B$ tranches than in the base case in Exhibit 4. As expected, the results show that lower subordination levels shift credit risk from lower-grade tranches to mid-level investment-grade tranches.

In the next comparative analysis we simulate the impact of an upward sloping yield curve on CMES credit risk premiums. With interest rates at or near historically low levels, it is important to understand how rising interest rates might affect the valuation of CMBS tranches. The simulation results presented in Exhibit 6 employ a moderately upward-sloping (100 basis point increase from a two-year to a ten-year U.S. Treasury security) and a steeply upward-sloping yield curve (200 basis point increase from a two-year to a ten-year 
U.S. Treasury security), which suggests higher interest rates in the future.

The impact of rising interest rates on whole-loan risk premiums is modest and attributable mainly to higher balloon risk. Yet changes in CMBS risk premiums are dramatic, especially for a steeply upwardsloping yield curve (Panel B in Exhibit 6). Investment-grade tranche total and balloon risk premiums (not including the AAA) almost double, while the impact on the non-investment-grade tranches of a steeply upward-sloping yield curve is more muted. Here again, the effect on total credit risk and balloon risk of higher interest rates in the future most significantly impacts the mid-range investment-grade tranches and does not as strongly impact the BB and B investment tranches. Interpreting the impact of interest-only loans on CMBS credit risk premiums is complicated. At the whole-loan level, as amortization reduces the loan balance over time, the possibility of default is reduced if LTV is the only default trigger. When property cash flow is also taken into account, interest-only loans may have lower default risk due to the higher initial DSC (note that at origination we use the same LTV for both amortizing and interest-only loans, so that the LTV is likely to limit the loan size and not the DSC).

In our simulation analyses, commercial mortgages with a $30 y e a r$ amortization schedule (the base case) have an initial DSC ratio of 1.40 , while an interest-only loan with the same LTV has an initial DSC of 1.58. As a result, a mortgage pricing model that ignores the cash flow default condition likely overstates the probability of term default.

While including the cash flow default trigger reduces the probability or the frequency of term default, loss severity increases dramatically for interest-only mortgages. The combination of lower default frequency and higher loss severity shifts part of the default risk from the lowest-rated subordinate tranches to investment-grade tranches, as lower-rated tranches maintain a positive cash flow from the investment for a longer period.

In Exhibit 7, the simulation results reveal that term default risk premiums for non-investment-grade tranches either decline or stay the same; the risk premiums on all investment-grade tranches increase.

As the term default probability declines, it becomes more likely that a loan reaching maturity will not meet contemporaneous refinancing requirements due to significantly weaker property or space 
market fundamentals. As a result, the whole-loan balloon risk premiums rise, and the higher risk affects the investment-grade CMBS tranches disproportionately. Here again, term default frequency is reduced, while term default and balloon loss severity is increased. ${ }^{11}$

\section{Conclusion}

Using a contingent claims commercial mortgage pricing model in a multi tranche CMBS framework, we attempt to quantify the impact of balloon risk on CMBS investments. In the first stage of a two-stage analysis, we use a double-trigger default model (a property cash flow trigger and an asset value trigger) to project whole-loan cash flows. In the second stage, the whole-loan cash flows are pooled and allocated to the various CMBS tranches. The value and risk premiums of each tranche are then calculated using Monte Carlo simulation.

We also complete a series of analyses under changing pool characteristics and market conditions, including lower subordination levels, interest-only loans, and higher mortgage interest rates.

There are two significant findings in this research. First, balloon risk constitutes a relatively small portion of total credit risk at the whole-loan level (less than $10 \%$ of the total credit risk premium is attributable to balloon risk).Second, while balloon credit risk premiums are low at the whole-loan level (3-7 basis points), this risk disproportionately and significantly impacts all but the highest-rated investment-grade CMBS tranches.

Balloon risk becomes a significant portion of the total credit risk premium for most investment-grade CMBS tranches, especially when more restrictive cash flow default triggers (such as higher property escrows) reduce the frequency of term default. As cash flow reserves prevent weaker properties from defaulting during the term of the loan, these properties become more vulnerable to balloon risk at maturity. The increase in loss severity from stringing along weak properties creeps into the pricing of the investment-grade tranches. Conversely, as non-investment grade CMBS tranches are kept in the deal with lower term default frequency, they receive interest payments longer in the face of deteriorating property fundamentals, and thus benefit from the reduction in loss frequency. 
NOT THE PUBLISHED VERSION; this is the author's final, peer-reviewed manuscript. The published version may be accessed by following the link in the citation at the bottom of the page.

\section{Appendix A: A Double-Trigger Default Model for Commercial Mortgages}

Most mortgage pricing studies assume monolithic default, i.e., the borrower defaults when the property value falls below the mortgage value. These default models have two major drawbacks. First, they ignore the borrower's cash flow position (i.e., a borrower would default even if the property net cash flow is sufficient to cover debt service). Second, they do not take into account default costs that are heterogeneous across borrowers.

To address these issues, we develop a double-trigger mortgage pricing model by modifying the Riddiough-Thompson [1993] fuzzy boundary default function and adding a cash flow default trigger.

Riddiough and Thompson [1993] introduce a commercial mortgage pricing model that endogenizes the effects of borrower default costs. The model's probability of default is a function of time to maturity and net equity in the property (illustrated in Exhibit $A$, where the net equity level is the ratio of property value over mortgage value).

The plot shows that the borrower is more likely to default when the net equity level is lower and/or the loan approaches maturity. For various reasons, including borrower reputation concerns and tax liability effects, however, a negative equity position does not always trigger default.

In our model, the borrower must incur a negative cash flow position in addition to an adverse net equity level to trigger default. Furthermore, a borrower is unlikely to default immediately when the DSC drops below 1.0. The borrower may fund a debt service shortfall through a property reserve account or other equity sources. Even when the borrower fails to make the payment, the master servicer advances the principal and interest payments if the shortfall is deemed temporary.

As a result, in the whole-loan pricing model, we assume that the borrower will default only when the net equity level is below one and the cumulative cash flow shortfall over a 12-month period exceeds a certain threshold (for example, one month or three months' debt service). 
NOT THE PUBLISHED VERSION; this is the author's final, peer-reviewed manuscript. The published version may be accessed by following the link in the citation at the bottom of the page.

\section{Appendix B: State Variables in the Default Model}

Three state variables are specified in the contingent claims model: interest rate, property value, and payout rate. Interest rate variations are assumed to follow the Cox-Ingersoll-Ross [1985] meanrevertingprocess: ${ }^{12}$

$$
d r=\kappa(\theta-r) d t+\sigma_{r} \sqrt{r} d z_{r}(\mathrm{~B}-1)
$$

where $\kappa$ is the speed of reversion parameter, $\theta$ is the long-term reversion rate, $\sigma_{r} \sqrt{r}$ is the standard deviation of changes in the current spot rate, and $d z_{r}$ is a standard Wiener process. A variety of shapes of the yield curve can be described by using a different initial interest rate, $r_{0}$.

Property values are assumed to follow a lognormal diffusion process:

$$
d P=\left(\alpha_{P}-\beta_{P}\right) P d t+\sigma_{\rho} P d z_{\rho}
$$

where $P$ is the property price, $\alpha_{P}$ is the expected total return on the property, $\beta_{P}$ is the continuous property income payout rate, $\sigma_{\rho}$ is a volatility parameter of property returns, and $d z_{\rho}$ is a standard Wiener process. To estimate the credit risk premium of commercial mortgages we apply the risk-neutral valuation principle, where the risk-neutral property price process is specified as:

$$
d P=\left(r-\beta_{P}\right) P d t+\sigma_{\rho} P d z_{\rho}
$$

and $r$ is the riskless spot rate. It is assumed that there is an instantaneous correlation between changes in property prices and interest rates, $\rho_{\mathrm{Pr}}$.

The third stochastic variable in the mortgage pricing model is property cash flow. Monthly property cash flow is determined by multiplying the property value by the property income payout rate, which is modeled as a function of contemporaneous market interest rates. Since interest rate and payout rate are correlated, we specify the payout rate as a linear function of interest rates plus a random volatility measure: ${ }^{13}$

$$
\beta_{P}=\alpha+\mathrm{b} \times \mathrm{r}+\varepsilon(\mathrm{B}-4)
$$


NOT THE PUBLISHED VERSION; this is the author's final, peer-reviewed manuscript. The published version may be accessed by following the link in the citation at the bottom of the page.

where $\beta_{P}$ is the property income payout rate, $r$ is the interest rate, $\alpha$ and $b$ are estimated parameters, and $\varepsilon$ is the residual. It is also assumed there is an autocorrelation term $\rho_{\varepsilon}$ between $\varepsilon_{t}$ and $\varepsilon_{t-1}$.

\section{Endnotes}

The insights and comments of Martha Peyton and David Jacob have significantly improved this research. The Real Estate Research Institute (RERI) provided financial support to complete this paper. The authors thank them all.

1. Most commercial mortgage pricing models in the academic literature use asset value as the sole default trigger, assuming that a borrower would default if and only if the property value is below the mortgage value (examples are Titman and Torous [1989], Kau et al. [1990], Childs, Ott, and Riddiough [1996], and Ciochetti and Yandell [1999]). Rational borrowers, however, would not default during the term of the loan if the property is generating sufficient cash flow to cover the debt service, even when the equity is negative. Therefore, adding a cash flow trigger as a necessary default condition that more accurately reflects borrower behavior. Jacob, Hong, and Lee [1999] consider property NOI as a default trigger, but they do not address balloon risk.

Most pricing models also assume that the balloon balance is immediately paid off at maturity if default conditions are not met, ignoring the possibility that the borrower might not be able to pay off the mortgage in full.

2. The backward numeric approach is preferred by many academic researchers as it explicitly measures the value of embedded default options in a mortgage. We use the Monte Carlo simulation approach for three primary reasons. First, we consider a double-trigger mortgage default model (i.e., one that considers both asset value and cash flow as default triggers), where three state variables are used to price a single mortgage: property cash flows, mortgage interest rates, and property values. When the model is applied to value a mortgage pool with $N$ loans, $(2 N+1)$ state variables are incorporated. This type of valuation problem becomes intractable using a backward numerical method, as computation time increases exponentially with the number of state variables. Monte Carlo simulation permits the use of a large number of state variables and provides more flexibility to reflect changing market conditions.

A second general criticism of mortgage and CMBS pricing models is their inability to capture real estate cycles and differences

Journal of Portfolio Management, Vol. 31, No. 5 (September 2005): pg. 114-123. DOI. This article is (C) Institutional Investor, Inc. and permission has been granted for this version to appear in e-Publications@Marquette. Institutional Investor, Inc. does not grant permission for this article to be further copied/distributed or hosted elsewhere without the express permission from Institutional Investor, Inc. 
across markets and property types (see Hudson- Wilson and Pappadopoulos [1999]). We find this a valid criticism and have incorporated these factors into the stochastic property valuation process and the income correlation between individual properties.

The third limitation is that the backward numeric method requires the specification of terminal conditions at maturity, and then works backward in time to derive the mortgage value. If we take into account the possibility of Ioan extension, terminal conditions cannot be specified at the originally scheduled maturity. As a result, the forwardlooking Monte Carlo approach provides the only reasonable means of valuing multitranche CMBS using a double-trigger term default and balloon risk model.

3. In the double-trigger default model, the borrower must incur a negative cash flow position and a negative net equity level to consider default. In other words, a DSC of less than and an LTV of higher than 1.0 are both necessary conditions for default.

4. While a range of mortgage extension fees and rules can be imposed that vary widely among the different mortgage loan agreements, our extension parameters are reflective of what many special servicers impose on mortgage loans that are extended beyond the mortgage maturity date (see Jacob and Fastovsky [1999]).

5. Commercial mortgage pricing studies have generally presumed noncallable mortgages (see Titman and Torous [1989], Riddiough and Thompson [1993], and Childs, Ott, and Riddiough [1996]). Most commercial mortgages have lockout periods and strict prepayment penalties in the form of defeasance and yield maintenance prepayment penalties.

Parameters related to the stochastic processes of the three state variables include: a flat yield curve $\left(r_{0}=7.5 \%, \kappa=25 \%, \theta=\right.$ $7.5 \%$, and $\sigma_{\mathrm{r}}=8.0 \%$ ), a property return volatility of $15 \%$, a zero correlation between property value and interest rate, and an initial property payout rate of $7.8 \%$. These assumptions are consistent with Esaki, L'Heureux, and Snyderman [1999] and Esaki and Goldman [2004].

6. For example, see the "Fitch Commercial Mortgage Presale Report" [2003]. Its summary statistics reveal that $82 \%$ of all mortgages in the pool have capital reserve requirements and $87 \%$ have upfront or ongoing expense reserve requirements.

Journal of Portfolio Management, Vol. 31, No. 5 (September 2005): pg. 114-123. DOI. This article is (C) Institutional Investor, Inc. and permission has been granted for this version to appear in e-Publications@Marquette. Institutional Investor, Inc. does not grant permission for this article to be further copied/distributed or hosted elsewhere without the express permission from Institutional Investor, Inc. 
NOT THE PUBLISHED VERSION; this is the author's final, peer-reviewed manuscript. The published version may be accessed by following the link in the citation at the bottom of the page.

7. CMBS subordination levels have fallen dramatically over the 1998-2004 period. As 2004 subordination levels were at all-time lows, we feel an average subordination level over a relevant analysis period may be more reflective of the market and allow us to later test the impact of changing subordination levels on the pricing of CMBS investment tranches.

8. Jacob and Fastovsky [1999] reveal similar findings for trouble loans that are modified.

9. Interest-only strips (IOs) in CMBS are often assigned AAA ratings. The unique characteristics of this type of investment make it inappropriate to consider the credit risk of an 10 equivalent to that of an AAA-rated CMBS investment tranche. We focus on the impact of balloon risk on bond classes with non-notional principal balances.

10. For example, with a $6.50 \%$ mortgage constant, the cost of keeping the option open is $1.625 \%$ of the loan amount at origination in the threemonth reserve scenario.

11. We have completed additional simulation analyses; examples include changing underwriting standards at the time of refinancing, using different cash flow payout rates, and changing the borrower's ability to self-fund the balloon payment shortfall. In all cases where balloon risk increases at the whole-loan level, investment-grade CMBS tranches are disproportionately affected. The patterns are consistent with those scenarios presented in the comparative analyses section; investors in mid-level investment-grade tranches bear most of the increase in balloon risk.

12. Levin [2004, p. 77] compares term structure models and finds that "any volatility model between the normal one and the square root seems to be a decent choice." An example of the square root models, the CoxIngersoll-Ross model is the most commonly used in the mortgage pricing literature.

13. Data on commercial property income payout rates are not available, so we estimate the relationship between payout rates and interest rates using property capitalization rates as a proxy. A regression of capitalization rates on mortgage contract rates is estimated using ACLI data. A similar approach is taken by Goldberg and Capone [2002]. 
NOT THE PUBLISHED VERSION; this is the author's final, peer-reviewed manuscript. The published version may be accessed by following the link in the citation at the bottom of the page.

\section{References}

Childs, P.D., S.H. Ott, and T.J. Riddiough. "The Pricing of Multiclass Commercial Mortgage-Backed Securities." Journal of Financial and Quantitative Analysis, 31 (1996), pp. 581-603.

Ciochetti, B.A., and K.D. Vandell. "The Performance of Commercial Mortgages." Real Estate Economics, 27 (1999), pp. 27-61.

"CMBS Market Watch Weekly." Credit Suisse First Boston, February 18, 2005.

"Commercial Mortgage Presale Report: GE Capital Commercial Mortgage Corporation." Fitch Ratings. Series 2003-C2, 2003.

Cox, J.C., J.E. Ingersoll, and S.A. Ross. "A Theory of the Term Structure of Interest Rates." Econometrica, 53 (1985), pp. 385-407.

Esaki, H., and M. Goldman. "Commercial Mortgage Defaults: 30 Years of History." CMBS Perspectives, September 17, 2004, pp.3-9.

Esaki, H., S. L'Heureux, and M. Snyderman. "Commercial Mortgage Defaults: An Update." Real Estate Finance, 16 (1999), pp. 80-86.

Goldberg, L., and C.A. Capone. "A Dynamic Double-Trigger Model of Multifamily Mortgage Default." Real Estate Economics, 30 (2002), pp. 85-113.

Hudson-Wilson, S., and G.J. Pappadopoulos. "CMBS and the Real Estate Cycle." The Journal of Portfolio Management, 25 (1999), pp. 105-111.

Jacob, D.P., and P. Fastovsky. "Understanding and Managing the Balloon Risk of Commercial Mortgages in CMBS." In F.J. Fabozzi and D.P.Jacob, eds., The Handbook of Commercial Mortgage-Backed Securities, 2nd ed. New Hope, PA: Frank J. Fabozzi Associates, 1999, pp. 275-285.

Jacob, D.P., T. Hong, and L.H. Lee. "An Options Approach to Commercial Mortgages and CMBS Valuation and Risk Analysis." In F.J. Fabozzi and D.P.Jacob, eds., The Handbook of Commercial Mortgage-Backed Securities, 2nd ed. New Hope, P A: Frank J. Fabozzi Associates, 1999, pp. 317-346.

Kau, J.B., D.C. Keenan, W.S. Muller, and J.F. Epperson. "Pricing Commercial Mortgages and Their Mortgage-Backed Securities." Journal of Real Estate Finance and Economics, 3 (1990), pp. 333-356.

Lehman, R., M.S. Freydberg, and J. Tcherkassova. "Extension Risk Has Grown But Quantifying it Remains Elusive." Merrill Lynch CMBS Weekly, July 28, 2004, pp. 2-4.

Levin, A. "Interest Rate Model Selection." The Journal of Portfolio Management, 30 (2004), pp. 74-86.

Riddiough, T.J., and H.E. Thompson. "Commercial Mortgage Pricing with Unobservable Borrower Default Costs." Journal of the American Real Estate and Urban Economics Association, 21 (1993), pp. 265-291.

Titman, S., and W. Torous. "Valuing Commercial Mortgages: An Empirical Investigation of the Contingent-Claims Approach to Pricing Risky Debt." Journal of Finance, 44 (1989), pp. 345-373. 
NOT THE PUBLISHED VERSION; this is the author's final, peer-reviewed manuscript. The published version may be accessed by following the link in the citation at the bottom of the page.

Tu, C., and M. Eppli. "Term Default, Balloon Risk, and Credit Risk in Commercial Mortgages." The Journal of Fixed Income, 13 (2003), pp. 42-52.

\section{Exhibits}

\section{Exhibit 1: Subordination Levels of CMBS Tranches}

Image unavailable due to third-party copyright restrictions. Please see definitive published version to view image: http://dx.doi.org/10.3905/jpm.2005.593894

Exhibit 2: Interest-Only Loans in Conduit CMBS

Image unavailable due to third-party copyright restrictions. Please see definitive published version to view image: http://dx.doi.org/10.3905/jpm.2005.593894

\section{Exhibit 3: Term Default Risk Premiums of CMBS Tranches (in basis points)*}

\begin{tabular}{lcrcrrrc}
\hline & AAA & AA & A & BBB & BB & B & $\begin{array}{c}\text { Whole } \\
\text { Loan }\end{array}$ \\
\hline Model 1* & 0 & 4 & 24 & 99 & 389 & 1436 & 81 \\
Model 2 & 0 & 7 & 34 & 124 & 421 & 1353 & 79 \\
Model 3 & 0 & 12 & 41 & 119 & 350 & 997 & 64 \\
\hline
\end{tabular}

*Model 1 is a single-Irigger, asset value-only default model. Models 2 and 3 are double-trigger default models where the borrower is assumed to have sufficient reserves to fund a one-month (Model 2) and three-month (Model 3) cumulative debt service shortfall in the previous year. 
NOT THE PUBLISHED VERSION; this is the author's final, peer-reviewed manuscript. The published version may be accessed by following the link in the citation at the bottom of the page.

Exhibit 4: Credit Risk Premiums of CMBS Tranches (including balloon risk)-Base Case

Panel A. Total Credit Risk Premiums (bp)

\begin{tabular}{rrrrrrrc}
\hline & AAA & AA & A & BBB & BB & B & $\begin{array}{c}\text { Whole } \\
\text { Loan }\end{array}$ \\
\hline Model 1 & 0 & 5 & 28 & 114 & 422 & 1486 & 84 \\
Model 2 & 0 & 8 & 41 & 144 & 464 & 1409 & 84 \\
Model 3 & 0 & 16 & 54 & 150 & 412 & 1081 & 71 \\
\hline
\end{tabular}

Panel B. Balloon Risk Premiums $(b p)^{*}$

\begin{tabular}{cccccccc} 
& AAA & AA & A & BBB & BB & B & $\begin{array}{c}\text { Whole } \\
\text { Loan }\end{array}$ \\
\hline Model 1 & 0 & 1 & 4 & 15 & 33 & 50 & 3 \\
Model 2 & 0 & 1 & 7 & 20 & 43 & 56 & 5 \\
Model 3 & 0 & 4 & 13 & 31 & 62 & 84 & 7 \\
\hline
\end{tabular}

* The balloon risk premium is the difference between the total credit risk premiums presented in Panel $A$ and the term default risk premiums presented in Exhibit 3.

Exhibit 5: Impact of Lower Subordination Levels on CMBS Tranches

\begin{tabular}{lccccccc}
\hline & AAA & AA & A & BBB & BB & B & $\begin{array}{c}\text { Whole } \\
\text { Loan }\end{array}$ \\
\hline Total Credit Risk & 3 & 97 & 176 & 379 & 758 & 1091 & 71 \\
Change from Base Case & 3 & 81 & 122 & 229 & 346 & 10 & 0 \\
& & & & & & & \\
Term Default Risk & 2 & 74 & 141 & 321 & 683 & 994 & 64 \\
Change from Base Case & 2 & 62 & 100 & 202 & 333 & -3 & 0 \\
& & & & & & & \\
Balloon Risk & 1 & 23 & 35 & 58 & 75 & 97 & 7 \\
Change from Base Case & 1 & 19 & 22 & 27 & 13 & 13 & 0 \\
\hline
\end{tabular}

Journal of Portfolio Management, Vol. 31, No. 5 (September 2005): pg. 114-123. DOI. This article is (C) Institutional Investor, Inc. and permission has been granted for this version to appear in e-Publications@Marquette. Institutional Investor, Inc. does not grant permission for this article to be further copied/distributed or hosted elsewhere without the express permission from Institutional Investor, Inc. 
NOT THE PUBLISHED VERSION; this is the author's final, peer-reviewed manuscript. The published version may be accessed by following the link in the citation at the bottom of the page.

Exhibit 6: Impact of Different Shapes of Yield Curve on CMBS

Tranches

Panel A. Moderately Upward-Sloping Yield Curve

\begin{tabular}{lcrrrrrr}
\hline & AAA & AA & A & BBB & BB & B & $\begin{array}{c}\text { Whole } \\
\text { Loan }\end{array}$ \\
\hline Total Credit Risk & 0 & 27 & 74 & 183 & 454 & 1097 & 75 \\
Change from Base Case & 0 & 11 & 20 & 33 & 42 & 16 & 4 \\
& & & & & & & \\
Term Default Risk & 0 & 18 & 55 & 143 & 380 & 993 & 65 \\
Change from Base Case & 0 & 6 & 14 & 24 & 30 & -4 & 1 \\
& & & & & & & \\
Balloon Risk & 0 & 9 & 19 & 40 & 74 & 104 & 10 \\
Change from Base Case & 0 & 5 & 6 & 9 & 12 & 20 & 3 \\
\hline
\end{tabular}

Panel B. Steeply Upward-Sloping Yield Curve

\begin{tabular}{lrrrrrrr}
\hline & AAA & AA & A & BBB & BB & B & $\begin{array}{c}\text { Whole } \\
\text { Loan }\end{array}$ \\
\hline Total Credit Risk & 1 & 28 & 82 & 198 & 472 & 1124 & 80 \\
Change from Base Case & 1 & 12 & 28 & 48 & 60 & 43 & 9 \\
Term Default Risk & 1 & 18 & 55 & 145 & 380 & 991 & 65 \\
Change from Base Case & 1 & 6 & 14 & 26 & 30 & -6 & 1 \\
& & & & & & & \\
Balloon Risk & 0 & 10 & 27 & 53 & 92 & 133 & 15 \\
Change from Base Case & 0 & 6 & 14 & 22 & 30 & 49 & 8 \\
\hline
\end{tabular}

Journal of Portfolio Management, Vol. 31, No. 5 (September 2005): pg. 114-123. DOI. This article is @ Institutional Investor, Inc. and permission has been granted for this version to appear in e-Publications@Marquette. Institutional Investor, Inc. does not grant permission for this article to be further copied/distributed or hosted elsewhere without the express permission from Institutional Investor, Inc. 
NOT THE PUBLISHED VERSION; this is the author's final, peer-reviewed manuscript. The published version may be accessed by following the link in the citation at the bottom of the page.

\section{Exhibit 7: Impact of Interest-Only Loans on CMBS Tranches}

\begin{tabular}{lccccccc}
\hline & AAA & AA & A & BBB & BB & B & $\begin{array}{c}\text { Whole } \\
\text { Loan }\end{array}$ \\
\hline Total Credit Risk & 1 & 48 & 101 & 198 & 409 & 786 & 73 \\
Change from Base Case & 1 & 32 & 47 & 48 & -3 & -295 & 2 \\
& & & & & & & \\
Term Default Risk & 0 & 28 & 68 & 149 & 354 & 738 & 58 \\
Change from Base Case & 0 & 16 & 27 & 30 & 4 & -259 & -6 \\
& & & & & & & \\
Balloon Risk & 1 & 20 & 33 & 49 & 55 & 48 & 15 \\
Change from Base Case & 1 & 16 & 20 & 18 & -7 & -36 & 8 \\
\hline
\end{tabular}

\section{Exhibit A: Default Probability Functions}

Image unavailable due to third-party copyright restrictions. Please see definitive published version to view image: http://dx.doi.org/10.3905/jpm.2005.593894 